\title{
Seasonal Changes in Nutritive Value of Some Grass Species in West Sumatra, Indonesia
}

\author{
Evitayani $^{1}$, L. Warly ${ }^{2}$, A. Fariani ${ }^{3}$, T. Ichinohe ${ }^{4}$ and T. Fujihara ${ }^{4, *}$ \\ ${ }^{1}$ The United Graduate School of Agriculture Sciences, Tottori University, Tottori 680-8533, Japan \\ ${ }^{4}$ Laboratory of Animal Science, Faculty of Life and Environmental Science, Shimane University \\ Matsue-shi 690-8504, Japan
}

\begin{abstract}
This study was carried out to evaluate the potential nutritive value of commonly found grasses collected at native pasture in West Sumatra, Indonesia during dry and rainy seasons. Variables measured included chemical composition, in vitro digestibility, concentration of $\mathrm{Ca}, \mathrm{P}$ and $\mathrm{Mg}$, gas production and metabolizable energy (ME) content of the grasses. The results showed that species and season had significant effect on chemical composition and mineral concentration. Crude protein content in the dry season ranged from $6.5 \%$ (B. decumbens) to $14.4 \%$ (P. maximum) and increased slightly from $7.8 \%$ (B. decumbens) to 14 . $8 \%$ (A. compressus) in the rainy season. Data on fiber fraction showed that grass contained more NDF, ADF and ADL in dry season than in rainy season. Data on mineral concentration showed that $C$. plectostachyus and $P$. maximum in dry season had higher Ca than those of other species, while in rainy season $P$. maximum had highest Ca concentration. In dry season, the DMD varied from $50.4 \%(P$. purpuphoides) to $59.1 \%$ (P. purpureum), while in rainy season ranged from $50.3 \%$ (A. gayanus) to $61.8 \%$ (P. purpureum). The potential and rate of gas production were significantly $(\mathrm{p}<0.05)$ affected by species and season. During dry season, potential of gas production ranged from $21.8 \mathrm{ml} / 200 \mathrm{mg}$ (A. compressus) to $45.1 \mathrm{ml} / 200 \mathrm{mg}$ (C. plectostachyus), while in rainy season it varied from $35.6 \mathrm{ml} / 200$ $\mathrm{mg}$ (A. gayanus) to $47.5 \mathrm{ml} / 200 \mathrm{mg}$ (P. purpureum). ME content of grasses varied from 6.0 to $8.3 \mathrm{MJ} / \mathrm{kg}$ in dry season and increased slightly from 6.4 to $8.6 \mathrm{MJ} / \mathrm{kg}$ in rainy season. Both in dry and rainy seasons, the highest ME content was occurred in $P$. purpureum and C. plectostachyus. In conclusion, nutritive value of the observed grasses in West Sumatra, Indonesia was relatively higher during rainy season compared with dry season. Pennisetum purpureum and Cynodon plectostachyus had the best nutritive value in both dry and rainy seasons. (Asian-Aust. J. Anim. Sci. 2004. Vol 17, No. 12 : 1663-1668)
\end{abstract}

Key Words : Dry Season, Wet Season, Grass Species, Nutritive Value

\section{INTRODUCTION}

In smallholders farming systems, native forages and agriculture by products are the main feed source for ruminants in Indonesia. According to Nitis et al. (1980), the botanical composition of the forage fed during wet season consists $35 \%$ grass and $65 \%$ shrub and tree fodders, while during dry season it consists $6 \%$ grass and $94 \%$ shrub and tree fodders. The potential of any feed to support animal production depends on the quantity eaten and extent to which the feed consumed supplies energy, protein, mineral and vitamin requirements (Minson, 1990). Many tropical grasses have been studied in both laboratory and feeding practices. The nutritive value of forages is a result of the combined effects of genetic and environmental factors. The genetic factors include species, strain within species, type of growth and the response to environmental factors. Some

\footnotetext{
* Corresponding Author: Tsutomu Fujihara. Tel: +81-852-326584, Fax: +81-852-32-6537, E-mail: fujihara@life.shimane-u. ac.jp

2 Faculty of Animal Husbandry, Andalas University, Padang 25163, Indonesia.

${ }^{3}$ Faculty of Agriculture, Sriwijaya University, Palembang 30139, Indonesia.

Received November 13, 2003; Accepted June 4, 2004
}

environmental factors are climate, weather, soil fertility, fertilizer application and management (Sullivan, 1973). Previous study showed that nutritive value of legumes assessed by nutrient digestibility and metabolizable energy content greatly varied among the species and it was higher in rainy season than that in dry season (Evitayani et al., 2004). There was no information available concerning nutritive value of grass in West Sumatra in relation to season, therefore the aim of this study was to evaluate the nutritive value through determination of chemical composition, mineral concentration, in vitro digestibility, in vitro gas production and estimation of metabolizable energy (ME) content of grasses during dry and rainy seasons.

\section{MATERIALS AND METHODS}

\section{Experimental site}

This study was conducted in Padang (West Sumatra), Indonesia. The area is located in the tropical and monsoon region, and lies between $0^{\circ 30} \mathrm{~N}$ to $3^{\circ 30} \mathrm{~S}$ and between $98^{\circ 36}$ to $101^{\circ 53}$ East. There are two seasons during the year, dry season from February to September and rainy season from November to March. The temperature is nearly constant, differing only a few degrees among the dry and rainy seasons with daily temperature ranges from 22 to $32^{\circ} \mathrm{C}$, 
Table 1. Organic matter $(\mathrm{OM})$, crude protein $(\mathrm{CP})$ and ether extract (EE) content of grass species

\begin{tabular}{|c|c|c|c|c|c|c|c|c|c|}
\hline \multirow{2}{*}{ Species } & \multicolumn{2}{|c|}{$\mathrm{OM}$} & \multirow{2}{*}{$\mathrm{Se}^{\#}$} & \multicolumn{2}{|c|}{$\mathrm{CP}$} & \multirow{2}{*}{$\mathrm{Se}^{\#}$} & \multicolumn{2}{|c|}{$\mathrm{EE}$} & \multirow{2}{*}{$\mathrm{Se}^{\#}$} \\
\hline & Dry & Rainy & & Dry & Rainy & & Dry & Rainy & \\
\hline A. gayanus & $86.8^{\mathrm{a}}$ & $90.0^{\mathrm{bc}}$ & $*$ & $8.5^{\mathrm{ab}}$ & $11.1^{b}$ & NS & 1.8 & $2.9^{\mathrm{ab}}$ & $*$ \\
\hline A. compressus & $88.1^{\mathrm{ab}}$ & $86.6^{\mathrm{a}}$ & NS & $12.7^{\mathrm{cd}}$ & $14.8^{\mathrm{c}}$ & $*$ & 1.6 & $2.6^{\mathrm{ab}}$ & $*$ \\
\hline B. decumbens & $90.4^{\mathrm{b}}$ & $93.3^{\mathrm{c}}$ & $*$ & $6.5^{\mathrm{a}}$ & $7.8^{\mathrm{a}}$ & NS & 1.5 & $2.3^{\mathrm{a}}$ & NS \\
\hline C. plectostachyus & $86.2 \mathrm{a}$ & $88.5^{\mathrm{ab}}$ & NS & $13.8^{\mathrm{d}}$ & $12.7^{\mathrm{bc}}$ & NS & 2.3 & $3.1^{\mathrm{ab}}$ & NS \\
\hline P. maximum & $89.9^{\mathrm{ab}}$ & $88.7^{\mathrm{ab}}$ & NS & $14.4^{\mathrm{d}}$ & $12.9^{\mathrm{bc}}$ & $*$ & 1.7 & $3.7^{\mathrm{b}}$ & $*$ \\
\hline P. purpuphoides & $86.2^{\mathrm{a}}$ & $88.0^{\mathrm{ab}}$ & NS & $9.5^{\mathrm{b}}$ & $12.6^{\mathrm{bc}}$ & $*$ & 2.3 & $2.8^{\mathrm{ab}}$ & NS \\
\hline P. purpureum & $92.2^{\mathrm{b}}$ & $90.0^{\mathrm{bc}}$ & NS & $12.4^{\mathrm{cd}}$ & $13.7^{\mathrm{bc}}$ & NS & 2.7 & $3.1^{\mathrm{ab}}$ & NS \\
\hline Mean & 88.5 & 88.9 & & 11.1 & 11.7 & & 2.0 & 2.5 & \\
\hline
\end{tabular}

${ }^{\#}$ Se: Effect of season in the same species of grass. ${ }^{*} \mathrm{p}<0.05$, NS: Not significant.

${ }^{a}, b, c, d$ Values in the same column with different superscripts differ significantly $(p<0.05)$.

with humidity about $86 \%$. The means of monthly rainfall in dry and wet seasons are 192.2 and $298.4 \mathrm{~mm}$, respectively.

\section{Collection of grass samples}

The forage evaluated consisted of seven grasses species (Andropogon gayanus, Axonopus compressus, Brachiaria decumbens, Cynodon plectostachyus, Panicum maximum, Pennisetum purpuphoides and Pennisetum purpureum) representing common grass fed to ruminants in West Sumatra. The forages were collected from native pasture during dry and rainy seasons. The samples were dried at $60^{\circ} \mathrm{C}$ for $48 \mathrm{~h}$ and then coarsely milled to pass a $1 \mathrm{~mm}$ screen for further analysis. Chemical composition of the forages were analyzed by the standard method of the Association of Official Analytical Chemist (AOAC, 1984); while NDF, ADF and acid detergent lignin (ADL) contents were determined according to the procedures of Goering and Van Soest (1970). Concentration of Ca, P and Mg were analyzed by Inductively Coupled Plasma Emission Spectrometer (ICPS-2000, Shimadzu, Japan) after hydrochloric acid digestion.

\section{Determination of in vitro digestibility, gas production} and metabolizable energy content

In vitro digestibility of dry matter (DMD), organic matter (OMD) and crude protein (CPD) of the foragesamples were determined by the method of Tilley and Terry (1963) and Goering and Van Soest (1973). The rumen fluid for measurement of in vitro digestibility and gas production was taken from healthy mature Japanese Corriedale sheep fitted with permanent rumen cannulae $(\varnothing=70 \mathrm{~mm})$. One part of the rumen fluid was mixed with two parts of the medium consisting of in vitro rumen buffer solution, macro and micro mineral solutions, resazurine and reduction solution. One gram of each sample was incubated in the rumen fluid-buffer medium mixture through at $39 \pm 0.1^{\circ} \mathrm{C}$ for $96 \mathrm{~h}$. After the in vitro degradation trials, all the incubated materials were filtered and then dried at $60^{\circ} \mathrm{C}$ for $96 \mathrm{~h}$ to determine DMD. The residues were analyzed for crude protein $(\mathrm{CP})$ and organic matter $(\mathrm{OM})$ to determine OMD and CPD.
In vitro gas production was measured with syringes according to the method described by Menke and Steingass (1988). The produced gas was read at a series of incubation times, i.e. 3, 6, 12, 24, 48, 72 and 96 h. The exponential equation proposed by Ørskov and McDonald (1979) was used to determine characteristics of gas production using Neway-Exel computer program (Macaulay Institute, Aberdeen, UK). The equation was: $\mathrm{Y}=\mathrm{a}+\mathrm{b}\left(1-\mathrm{e}^{-\mathrm{ct}}\right)$, where: $\mathrm{Y}=$ the volume of the gas produced with time $(\mathrm{t}) ; \mathrm{a}=$ the intercept of the gas production curve; $b=$ the asymptote and $\mathrm{c}=$ the rate of gas production $(\mathrm{ml} / \mathrm{h})$. The value of $(\mathrm{a}+\mathrm{b})$ represented the potential extent of in vitro gas production. The metabolizable energy (ME) content of the forages was estimated according to the following equation (Menke and Steingass, 1988): $\mathrm{ME}(\mathrm{MJ} / \mathrm{kg} \mathrm{DM})=2.2+0.136\left(\mathrm{GP}_{24 \mathrm{~h}}\right)+$ $0.0057(\mathrm{CP})+0.00029 \mathrm{EE})^{2}$. Where: $\mathrm{ME}=$ metabolizable energy; $\mathrm{GP}=$ gas production at $24 \mathrm{~h}$ incubation time; $\mathrm{CP}=$ crude protein content of the forage $(\mathrm{g} / \mathrm{kg})$ and $\mathrm{EE}=$ ether extract (crude fat) content of the forage $(\mathrm{g} / \mathrm{kg})$.

\section{Statistical analysis}

Results of the chemical composition, macro mineral, in vitro degradability, in vitro gas production and metabolizable energy were analyzed using General Linear Model (GLM) procedure for computations of means and standard errors, according to SAS/Start View ${ }^{\circledR}$ (1999). The mean comparisons between the species of grasses and seasons were compared using probability of differences. The following statistical model was used in the analysis: $\mathrm{Y}_{\mathrm{ijk}}=\mu+\mathrm{S}_{\mathrm{i}}+\mathrm{F}_{\mathrm{k}}+\mathrm{e}_{\mathrm{ijk}}$. Where: $\mathrm{Y}_{\mathrm{ijk}}=$ dependent variable (general observation); $\mu=$ the overall mean; $\mathrm{S}_{\mathrm{i}}=$ effect of the $\mathrm{i}^{\text {th }}$ season ( $\mathrm{i}=\mathrm{dry}$ and rainy season); $\mathrm{Fk}=$ effect of $\mathrm{k}^{\text {th }}$ species $(\mathrm{k}=1,2 . ., 7) ; \mathrm{e}_{\mathrm{ijk}}=$ error term.

\section{RESULTS AND DISCUSSION}

\section{Chemical composition}

Chemical composition of the grasses was significantly $(\mathrm{p}<0.05)$ different among species and seasons (Table 1). Crude protein content in dry season ranged from $6.5 \%$ ( $B$. decumbens) to $14.4 \%$ (P. maximum) and increased slightly 
Table 2. Neutral detergent fiber (NDF), acid detergent fiber (ADF) and acid detergent lignin (ADL) content of grass in dry and rainy seasons (\% dry matter)

\begin{tabular}{|c|c|c|c|c|c|c|c|c|c|}
\hline \multirow{2}{*}{ Species } & \multicolumn{2}{|c|}{$\mathrm{NDF}$} & \multirow{2}{*}{$\mathrm{Se}^{\#}$} & \multicolumn{2}{|c|}{$\mathrm{ADF}$} & \multirow{2}{*}{$\mathrm{Se}^{\#}$} & \multicolumn{2}{|c|}{ ADL } & \multirow{2}{*}{$\mathrm{Se}^{\#}$} \\
\hline & Dry & Rainy & & Dry & Rainy & & Dry & Rainy & \\
\hline A. gayanus & $69.7^{b}$ & $70.8^{\mathrm{c}}$ & NS & $31.2^{b}$ & $36.9^{b}$ & $*$ & $7.3^{\mathrm{c}}$ & $3.9^{\mathrm{a}}$ & $* *$ \\
\hline A. compressus & $69.3^{b}$ & $62.0^{\mathrm{b}}$ & $*$ & $31.6^{\mathrm{b}}$ & $28.3^{\mathrm{a}}$ & NS & $6.5^{b c}$ & $4.8^{\mathrm{ab}}$ & $*$ \\
\hline B. decumbens & $69.3^{b}$ & $59.8^{\mathrm{ab}}$ & $* *$ & $26.5^{\mathrm{a}}$ & $35.7^{\mathrm{b}}$ & $* *$ & $6.7^{\mathrm{bc}}$ & $7.8^{\mathrm{c}}$ & NS \\
\hline C. plectostachyus & $58.0^{\mathrm{a}}$ & $57.3^{\mathrm{a}}$ & NS & $35.7^{\mathrm{c}}$ & $36.2^{\mathrm{b}}$ & NS & $4.4^{\mathrm{a}}$ & $3.7^{\mathrm{a}}$ & NS \\
\hline P. maximum & $62.9^{\mathrm{a}}$ & $60.3^{\mathrm{ab}}$ & NS & $44.6^{\mathrm{d}}$ & $44.1^{\mathrm{c}}$ & $\mathrm{NS}$ & $6.9^{\mathrm{bc}}$ & $6.3^{b c}$ & $\mathrm{NS}$ \\
\hline P. purpuphoides & $64.6^{\mathrm{b}}$ & $58.6^{\mathrm{ab}}$ & $*$ & $33.7^{\mathrm{bc}}$ & $29.4^{\mathrm{a}}$ & $*$ & $5.0^{\mathrm{a}}$ & $4.7^{\mathrm{ab}}$ & NS \\
\hline P. purpureum & 58.7 & 62.9 & $*$ & 38.7 & 28.5 & $* *$ & 6.0 & 3.7 & $*$ \\
\hline Mean & 64.3 & 63.0 & & 34.6 & 34.2 & & 6.1 & 5.5 & \\
\hline
\end{tabular}

\# Se: Effect of season in the same species of grass. ${ }^{*} \mathrm{p}<0.05,{ }^{* *} \mathrm{p}<0.01$, NS: Not significant.

a, b, c, d Values in the same column with different superscripts differ significantly $(\mathrm{p}<0.05)$.

Table 3. Concentration of $\mathrm{Ca}, \mathrm{P}$ and $\mathrm{Mg}$ in grass during dry and rainy seasons (g/kg DM)

\begin{tabular}{|c|c|c|c|c|c|c|c|c|c|}
\hline \multirow{2}{*}{ Species } & \multicolumn{2}{|c|}{$\mathrm{Ca}$} & \multirow{2}{*}{$\mathrm{Se}^{\#}$} & \multicolumn{2}{|c|}{$\mathrm{P}$} & \multirow{2}{*}{$\mathrm{Se}^{\#}$} & \multicolumn{2}{|c|}{$\mathrm{Mg}$} & \multirow{2}{*}{$\mathrm{Se}^{\#}$} \\
\hline & Dry & Rainy & & Dry & Rainy & & Dry & Rainy & \\
\hline A. gayanus & $6.6^{\mathrm{a}}$ & $8.9^{\mathrm{c}}$ & $*$ & $4.1^{b}$ & $2.4^{\mathrm{a}}$ & $*$ & $2.8^{\mathrm{ab}}$ & $3.3^{\mathrm{b}}$ & NS \\
\hline A. compressus & $7.1^{\mathrm{a}}$ & $7.4^{\mathrm{b}}$ & NS & $2.6^{\mathrm{a}}$ & $3.6^{\mathrm{b}}$ & NS & $4.0^{\mathrm{c}}$ & 4.4 & NS \\
\hline B. decumbens & $6.8^{\mathrm{a}}$ & $7.4^{\mathrm{b}}$ & NS & $2.3^{\mathrm{a}}$ & $2.2^{\mathrm{a}}$ & NS & $3.2^{\mathrm{bc}}$ & $3.8^{\mathrm{b}}$ & NS \\
\hline C. plectostachyus & $9.0^{\mathrm{b}}$ & $7.7^{\mathrm{b}}$ & $*$ & $4.4^{\mathrm{b}}$ & $4.7^{\mathrm{c}}$ & NS & $3.5^{\mathrm{bc}}$ & $2.0^{\mathrm{a}}$ & $*$ \\
\hline P. maximum & $9.4^{\mathrm{b}}$ & $10.7^{\mathrm{d}}$ & $*$ & $3.2^{\mathrm{a}}$ & $4.3^{\mathrm{bc}}$ & NS & $3.4^{\mathrm{bc}}$ & $3.5^{\mathrm{b}}$ & NS \\
\hline P. purpuphoides & $6.5^{\mathrm{a}}$ & $5.3^{\mathrm{a}}$ & $\mathrm{NS}$ & $4.6^{\mathrm{b}}$ & $3.8^{\mathrm{b}}$ & $*$ & $2.8^{\mathrm{ab}}$ & $2.2^{\mathrm{a}}$ & NS \\
\hline P. purpureum & $6.1^{\mathrm{a}}$ & $6.0^{\mathrm{a}}$ & NS & $2.8^{\mathrm{a}}$ & $5.9^{\mathrm{d}}$ & $* *$ & $2.3^{\mathrm{a}}$ & $3.2^{\mathrm{b}}$ & $*$ \\
\hline Mean & 7.4 & 7.6 & & 3.4 & 3.8 & & 3.1 & 3.2 & \\
\hline
\end{tabular}

${ }^{\#}$ Se: Effect of season in the same species of grass. ${ }^{*} \mathrm{p}<0.05,{ }^{*} \mathrm{p}<0.01$, NS: Not significant.

$\mathrm{a}, \mathrm{b}, \mathrm{c}, \mathrm{d}$ Values in the same column with different superscripts differ significantly $(\mathrm{p}<0.05)$.

from $7.8 \%$ (B. decumbens) to $14.8 \%$ (A. compressus) in rainy season. In general, data on fiber fraction showed that grass contained more NDF, ADF and ADL in dry season than in rainy season. The ranges of NDF, ADF and lignin content in dry seasons were from $58.0 \%$ (C. plectostachyus) to $69.7 \%$ (A. gayanus); $26.5 \%$ (B. decumbens) to $44.6 \%$ ( $P$. maximum) and from $4.4 \%$ (C. plectostachyus) to $7.3 \%$ (A. gayanus), respectively. In the rainy season the NDF, ADF and ADL contents decreased significantly $(p<0.05)$ with the values ranging from 57.3 (C. plectostachyus) to $70.8 \%$ (A. gayanus); $28.3 \%$ (A. compressus) to $44.1 \%$ (P. maximum) and from $3.7 \%$ (C. plectostachyus) to $7.8 \%$ (B. decumbens), respectively. $B$. decumbens, $P$. purpureum and $P$. purpuphoides had significantly lower $(p<0.05)$ NDF and $\mathrm{ADF}$ in rainy season compared to those of dry season; while ADL of $A$. gayanus, $A$. compressus and $P$. purpureum was lower in rainy season than in dry season. Such seasonal changes in tropical regions are routinely noticed and are due to maturity and the age of grass species with progress of season from dry to rainy seasons. The lower content of $\mathrm{CP}$ in dry season than that of rainy season was in agreement with other results for the legumes in West Sumatra (Göhl., 1975; Aregheore., 2002; Evitayani et al., 2004). The wide variation in CP and fiber of the forages was consistent with previous reports (Fariani., 1996; Ammar et al., 1999; Tudsri et al., 2002; Islam et al., 2003; Manyayu et al., 2003; Nasrullah et al., 2003). Minson (1990) showed that crude protein concentrations of 560 tropical forages samples, grown and determined in different parts of the world, ranged from $2 \%$ to $27 \%$ of the dry matter according to growth stage and soil fertility. The differences in fiber components between season suggested that the high intensity of solar radiation and less amount of rainfall caused faster maturation during dry season and this resulted in higher cell wall contents and lower cell contents than those of rainy season. It is well known that the amount of rainfall in dry season was $192.2 \mathrm{~mm} /$ month while 298.4 $\mathrm{mm} / \mathrm{month}$ in rainy season (Indonesia Statistical Bureau, 2001).

\section{Mineral concentrations}

Concentrations of mineral $\mathrm{Ca}, \mathrm{P}$ and $\mathrm{Mg}$ of are shown in Table 3. Both season and species significantly affected $\mathrm{Ca}$, $\mathrm{P}$ and $\mathrm{Mg}$ of grass $(\mathrm{p}<0.05)$. In dry season, $C$. plectostachyus and P. maximum contained higher amount of Ca than that of the other species, while in rainy season $P$. maximum contained the highest $\mathrm{Ca}$ concentration. Concentrations of $\mathrm{Ca}$ in $A$. gayanus and $P$. maximum were significantly $(p<0.05)$ decreased with the change of season from rainy to dry season. The mean of $\mathrm{P}$ concentration in rainy season was higher than that in dry season without significance $(3.8$ vs. $3.4 \mathrm{~g} / \mathrm{kg})$. In dry season, $C$. plectostachyus and $P$. purpuphoides contained higher $\mathrm{P}$ concentration, while in rainy season $P$. purpureum contained the highest $\mathrm{P}$ concentration. In Java island, Indonesia, $\mathrm{Ca}$ concentration of forages in rainy season was 
Table 4. In vitro digestibility of dry matter (DMD), organic matter (OMD) and crude protein (CPD) of grass in dry and rainy seasons $(\%)$

\begin{tabular}{|c|c|c|c|c|c|c|c|c|c|}
\hline \multirow{2}{*}{ Species } & \multicolumn{2}{|c|}{ DMD } & \multirow{2}{*}{$\mathrm{Se}^{\#}$} & \multicolumn{2}{|c|}{ OMD } & \multirow{2}{*}{$\mathrm{Se}^{\#}$} & \multicolumn{2}{|c|}{ CPD } & \multirow{2}{*}{$\mathrm{Se}^{\ddagger}$} \\
\hline & Dry & Rainy & & Dry & Rainy & & Dry & Rainy & \\
\hline A. gayanus & $51.6^{\mathrm{a}}$ & $50.3^{\mathrm{a}}$ & $\mathrm{NS}$ & $53.5^{\mathrm{a}}$ & 53.2 & NS & $55.6^{\mathrm{a}}$ & $56.4^{\mathrm{a}}$ & $\mathrm{NS}$ \\
\hline A. compressus & $53.7^{\mathrm{a}}$ & $55.0^{\mathrm{bc}}$ & NS & $53.1^{\mathrm{a}}$ & 59.3 & $*$ & $51.8^{\mathrm{a}}$ & $59.9^{\mathrm{ab}}$ & $*$ \\
\hline B. decumbens & $50.9^{\mathrm{a}}$ & $49.1^{\mathrm{a}}$ & NS & $52.3^{\mathrm{a}}$ & 52.4 & NS & $54.7^{\mathrm{a}}$ & $56.2^{\mathrm{a}}$ & NS \\
\hline C. plectostachyus & $52.7^{\mathrm{a}}$ & $57.7^{\mathrm{bc}}$ & $*$ & $54.1^{\mathrm{a}}$ & 63.0 & $* *$ & $60.3^{\mathrm{b}}$ & $61.2^{\mathrm{bc}}$ & NS \\
\hline P. maximum & $53.1^{\mathrm{a}}$ & $58.5^{\mathrm{cd}}$ & $*$ & $53.9^{\mathrm{a}}$ & 59.5 & $*$ & $54.3^{\mathrm{a}}$ & $59.6^{\mathrm{ab}}$ & $*$ \\
\hline P. purpuphoides & $50.4^{\mathrm{a}}$ & $54.8^{\mathrm{b}}$ & $*$ & $51.9^{\mathrm{a}}$ & 57.3 & $*$ & $54.2^{\mathrm{a}}$ & $60.5^{\mathrm{bc}}$ & $*$ \\
\hline P. purpureum & $59.1^{\mathrm{b}}$ & $61.8^{\mathrm{d}}$ & NS & $61.9^{b}$ & 62.3 & NS & $62.3^{\mathrm{b}}$ & $63.6^{\mathrm{c}}$ & NS \\
\hline Mean & 53.1 & 55.3 & & 54.4 & 56.3 & & 56.6 & 58.1 & \\
\hline
\end{tabular}

\# Se: Effect of season in the same species of grass. ${ }^{*} \mathrm{p}<0.05,{ }^{* *} \mathrm{p}<0.01$, NS: Not significant.

a, b, c, d Values in the same column with different superscripts differ significantly $(\mathrm{p}<0.05)$.

Table 5. Characteristics of in vitro gas production and metabolizable energy (ME) content of grass

\begin{tabular}{|c|c|c|c|c|c|c|c|c|c|}
\hline \multirow{2}{*}{ Species } & \multicolumn{2}{|c|}{$(a+b)^{1}$} & \multirow{2}{*}{$\mathrm{Se}^{\#}$} & \multicolumn{2}{|c|}{$\mathrm{c}^{2}$} & \multirow{2}{*}{$\mathrm{Se}^{\#}$} & \multicolumn{2}{|c|}{$\mathrm{ME}^{3}$} & \multirow{2}{*}{$\mathrm{Se}^{\#}$} \\
\hline & Dry & Rainy & & Dry & Rainy & & Dry & Rainy & \\
\hline A. gayanus & $35.6^{\mathrm{b}}$ & $35.6^{\mathrm{a}}$ & $\mathrm{Ns}$ & $0.042^{\mathrm{a}}$ & $0.065^{\mathrm{a}}$ & $*$ & $6.0^{\mathrm{a}}$ & $6.4^{\mathrm{a}}$ & $\mathrm{Ns}$ \\
\hline A. compressus & $21.8^{\mathrm{a}}$ & $36.9^{\mathrm{ab}}$ & $* *$ & $0.067^{\mathrm{b}}$ & $0.049^{\mathrm{a}}$ & $*$ & $6.3^{\mathrm{a}}$ & $6.7^{\mathrm{ab}}$ & Ns \\
\hline B. decumbens & $38.0^{\mathrm{bc}}$ & $39.1^{\mathrm{ab}}$ & Ns & $0.034^{\mathrm{a}}$ & $0.044^{\mathrm{a}}$ & $*$ & $6.3^{\mathrm{a}}$ & $6.7^{\mathrm{ab}}$ & Ns \\
\hline C. plectostachyus & $45.1^{\mathrm{d}}$ & $45.8^{\mathrm{c}}$ & Ns & $0.088^{\mathrm{c}}$ & $0.105^{\mathrm{b}}$ & $* *$ & $8.1^{\mathrm{d}}$ & $8.6^{\mathrm{c}}$ & $*$ \\
\hline P. maximum & $35.1^{\mathrm{bc}}$ & $41.7^{\mathrm{b}}$ & $* *$ & $0.094^{\mathrm{c}}$ & $0.059^{\mathrm{a}}$ & $* *$ & $7.1^{\mathrm{bc}}$ & $7.5^{\mathrm{abc}}$ & Ns \\
\hline P. purpuphoides & $39.7^{\mathrm{c}}$ & $40.3^{\mathrm{b}}$ & $\mathrm{Ns}$ & $0.141^{\mathrm{d}}$ & $0.136^{b c}$ & $\mathrm{Ns}$ & $7.5^{\mathrm{cd}}$ & $7.9^{\mathrm{bc}}$ & $\mathrm{Ns}$ \\
\hline P. purpureum & $44.1^{\mathrm{d}}$ & $47.5^{\mathrm{c}}$ & $*$ & $0.164^{\mathrm{d}}$ & $0.143^{\mathrm{c}}$ & $*$ & $8.3^{\mathrm{d}}$ & $8.6^{\mathrm{c}}$ & $\mathrm{Ns}$ \\
\hline Mean & 37.1 & 41.0 & & 0.081 & 0.086 & & 7.0 & 7.3 & \\
\hline
\end{tabular}

${ }^{\#}$ Se: Effect of season in the same species of grass. ${ }^{*} \mathrm{p}<0.05,{ }^{* *} \mathrm{p}<0.01$, NS: Not significant.

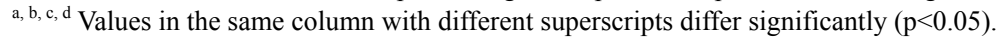

${ }^{1}$ Potential gas production (ml/200 mg DM). ${ }^{2}$ Production rate of constant $(\mathrm{ml} / \mathrm{h}) .{ }^{3} \mathrm{MJ} / \mathrm{kg} \mathrm{DM}$.

significantly $(p<0.01)$ higher than that of dry season, Kumagai et al. (1990). The $\mathrm{P}$ content in grass species also was slightly higher in rainy season than in dry season. Kumagai et al. (1990) also showed a similar trend for the P concentration in grass species, it tended to be higher in rainy season than in dry season. The Mg content in grass species were almost the same but tended to be higher in wet season than in dry season (Kumagai et al., 1990; Serra et al., 1997). According McDowell (1985), the critical level of Ca, $\mathrm{P}$ and $\mathrm{Mg}$ concentration in grass was $3.0,2.5$ and $2.0 \mathrm{~g} / \mathrm{kg}$, respectively. The present study showed there was no species of grasses deficient in $\mathrm{Ca}$ and $\mathrm{Mg}$, and only $\mathrm{B}$. decumbens contained $\mathrm{P}$ below the critical level in both dry and rainy seasons.

\section{In vitro digestibility}

The analysis of variance for digestibility showed that both species and season had significant effect on DMD, OMD and CPD of grasses $(p<0.05)$ (Table 4$)$. In dry season, the DMD varied form $50.4 \%$ (P. purpuphoides) to $59.1 \%$ (P. purpureum), while in rainy season ranged from $50.3 \%$ (A. gayanus) to $61.8 \%$ (P. purpureum). Effect of season showed that DMD and OMD of C. plectostachyus, P. maximum and P. purpuphoides were significantly higher $(\mathrm{p}<0.05)$ in rainy season compared to those of dry season. The higher DMD in rainy season compared to dry season was in agreement with the result of Nasrullah et al. (2003). The ranges of DMD in the present study were similar to those of reported by Manyayu et al. (2003), Poppi et al. (1981), Fariani (1996), Teguia et al. (1999) and Ammar et al. (1999). According to Bula et al. (1977), DMD of forage during the grazing stage can vary considerably, and is related to changes in the chemical composition particularly in fiber, lignin and silica contents. Digestibility of crude protein of grasses varied from $51.8 \%$ (A. compressus) to 62.3 (P. purpureum) in dry season and slightly increased in rainy season from $56.2 \%$ (B. decumbens) to $63.6 \%$ ( $P$. purpureum). The higher CPD in rainy season was similar with the result obtained by Göhl (1975) and the wide variation of CPD was mainly related to different content of crude protein in the grass and fiber component. Low CPdigestibility was associated with lower crude protein and higher fiber fractions (NDF, ADF and ADL) during dry season. Some differences in CPD of the forages also arise as a result of differences in species or genotype, stage of growth, environmental conditions and management practice. Generally, B. decumbens had relatively lower DMD, OMD and CPD than those of the other grasses. Otherwise, $P$. purpureum had higher DMD, OMD and CPD compared to the other grasses in both dry and rainy seasons. These findings were consistent with their chemical compositions as shown in Table 1, of which P. purpureum followed by $C$. 
plectostachyus contained much higher crude protein but was generally lower in cell wall constituents (CWC or $\mathrm{NDF}$ ) in both dry and rainy seasons.

\section{Gas production and ME contents}

Characteristics of in vitro gas production and estimated ME content of grasses during dry and rainy seasons are presented in Table 5. In general, gas production rapidly increased with increasing incubation time interval from $3 \mathrm{~h}$ to $48 \mathrm{~h}$ and it was relativly constant from $48 \mathrm{~h}$ to $96 \mathrm{~h}$ incubation times. The potential and rate of gas production were significantly affected by species and season $(p<0.05)$. During dry season, potential of gas production $(\mathrm{a}+\mathrm{b})$ ranged from $21.8 \mathrm{ml} / 200 \mathrm{mg}$ (A. compressus) to $45.1 \mathrm{ml} / 200 \mathrm{mg}$ (C. plectostachyus), while in rainy season it varied from 35.6 $\mathrm{ml} / 200 \mathrm{mg}$ (A. gayanus) to $47.5 \mathrm{ml} / 200 \mathrm{mg}$ (P. purpureum). Effect of season showed that potential gas production of $A$. compressus, $P$. maximum and $P$. purpureum was higher $(\mathrm{p}<0.05)$ in rainy season than in dry season. The highest rate of gas production (c) occurred in $P$. purpureum, either in dry or rainy season $(0.143$ and $0.164 \mathrm{ml} / \mathrm{h})$. Generally, $C$. plectostachyus followed by $P$. purpureum both in dry and rainy seasons had higher potential gas production. This finding indicated that the patterns of in vitro gas production were very similar to those of rumen DMD and OMD. As reported earlier, DMD, OMD were higher for $C$. plectostachyus and $P$. purpureum both in dry and wet seasons. This means that these grasses contained more degradable fractions than the other grasses that may have been fermented in the rumen and thus resulted in much higher volatile fatty acids (VFAs) and gas production (Fariani, 1996). The results were also in agreement with the observation of Menke et al. (1979), Krishnamoorthy et al. (1995) and Nogueria et al. (1999) that the amount of gas released when a feed is incubated in vitro with rumen fluid is closely related to the digestibility of the feed. As shown in Table 5, the ME content of grasses varied from 6.0 to 8.3 $\mathrm{MJ} / \mathrm{kg}$ in dry season and increased slightly from 6.4 to 8.6 $\mathrm{MJ} / \mathrm{kg}$ in rainy season. Both in dry and rainy seasons, the highest ME content occurred in $P$. purpureum and $C$. plectostachyus. The ME content of grasses in the present study was relatively higher compared to the ME content of several legumes in West Sumatra that varied from 6.4 to 7.8 $\mathrm{MJ} / \mathrm{kg}$ in dry season and from 6.9 to $7.8 \mathrm{MJ} / \mathrm{kg}$ in dry season (Evitayani et al., 2004).

From the above results, it could be concluded that nutritive value of the grasses grown in West Sumatra, Indonesia was relatively higher during rainy season compared with dry season. Pennisetum purpureum and Cynodon plectostachyus appeared to have better quality than other species. It suggested that proper supplementation with sources of nitrogen and energy might be required to support grazing ruminants, especially during dry season.

\section{REFERENCES}

Ammar, H. S., O. Lopez, R. Bochi-Brum, R. Garcia and M. J. Ranilla. 1999. Composition and in vitro digestibility of leaves and stems of grasses and legumes harvested from permanent mountain meadows at different stages of maturity. J. Anim. and Feed Sci. 8:599-610.

AOAC. 1990. Official Methods of Analysis. 15th edn. Association of Official Analytical Chemists. Arlington, Virginia.

Aregheore, E. M. 2002. Voluntary intake and digestibility of fresh, wilted and dry Leucaena (Leucaena leucochepala) at four levels to a basal diet of guinea grass (Panicum maximun). Asian-Aust. J. Anim. Sci. 15:1139-1146.

Bula, T. J., V. L. Lechtenberg and D. A. Holt. 1977. Potential of temperate zone cultivated forages. In: Potential of the world Forages for Ruminant Animal production, pp. 7-28. Winrock Intl. Livestock Res. Trg Cent., Arkansas.

Evitayani, L. Warly, A. Fariani, T. Ichinohe, S. A. Abdulrazak and T. Fujihara. 2004. Comparative rumen degradability of some legumes forages between wet and dry seasons in West Sumatra, Indonesia. Asian-Aust. J. Anim. Sci. 17:1107-1111.

Fariani, A.1996. The evaluation of nutritive value of forages by in situ and in vitro techniques. PhD Thesis. Shimane University, Japan.

Goering, H. G, and P. J. Van Soest. 1970. Forage fibre analysis (apparatus reagents, procedure and some application. Agricultural Handbook, 3799. ARS, USDA, Washington DC.

Goering, H. G. and P. J. Van Soest. 1973. Forage fibre analysis (apparatus reagents, procedure and some application). Agricultural Handbook, 3799. ARS, USDA, Washington DC.

Gőhl, B. O. 1975. Tropical feeds. Feeds information, summaries, and nutritive value. Rome, FAO.

Indonesian Statistical Bureau. 2001. The temperatures and annual rainfall in north and west Sumatra, Indonesia.

Islam, M. R., C. K. Saha, N. R. Sarker, M. Jahlil and M. Hasanuzzaman. 2003. Effect of variety on proportion of botanical fraction and nutritive value of different Napier grass (Pennisetum purpureum) and relationship between botanical fraction and nutritive value. Asian-Aust. J. Anim. Sci. 16:837842.

Kumagai, H., N. Ishida, M. Katsumata, H. Yano, R. Kawashima and J. Jachja. 1990. A study on nutritional status of macro minerals of cattle in Java in Indonesia. Asian-Aust. J. Anim. Sci. 2:7-13.

Krishnamoorthy, U., H. Soller, H. Steingass and K. H. Menke. 1995. Energy and protein evaluation of tropical feedstuffs for whole tract and ruminal digestion by chemical analyses and rumen inoculum studies in vitro. Anim. Feed Sci. Technol. 52:177-188.

Manyayu, G. J., C. Chakoma, S. Sibanda, C. Mutisi and I. C. Chakoma. 2003. The intake and palatability of four different types of Napier grass (Pennisetum purpureum) silage fed to sheep. Asian-Aust. J. Anim. Sci. 16:823-829.

McDowell, L. R. 1985. Nutrition of Grazing Ruminants in Warm Climates. p. 443. Academic Press, Orlando.

Menke, K. H., L. Raab, A. Salewski, H. Steingas, D. Fritz and W. Schneider. 1979. The estimation of digestibility and metabolizable energy of ruminats feeding stuffs from the gas 
production when they are incubated with rumen liquor in vitro. J. Agric. Sci. (Camb.). 93:217-222.

Menke, K. H. and H. Steinngas. 1988. Estimation of energetic feed value obtained from chemical analysis and in vitro gas production using rumen fluid. Anim. Res. Develop. 28:7-55.

Minson, D. J. 1990. The Chemical Composition and Nutritive Value of Tropical Grasses. In: (P. J. Skerman, D. G. Cameroon and F. Riveros) Tropical grasses. pp. 172-180. Food and Agriculture Organization of the United Nations, Rome.

Nasrullah, M., Niimi, R. Akashi and O. Kawamura. 2003. Nutritive evaluation of forage plants in South Sulawesi, Indonesia. Asian-Aust. J. Anim. Sci. 16:693-701.

Nitis, I. M., K. Lana, I. B. Sudana, N. Sutiji and I. G. N. Sarka. 1980. Survey data makanan ternak : Persediaan dan kebutuhan hijauan makanan ternak di Bali. pp. 1-218. Fakultas Kedokteran Hewan dan Peternakan Universitas Udayana, Denpasar, Bali, Indonesia.

Nogueria Filho, J. C. M. Fondevilla Barrios Urdaneta and A. Gonzalez Ronquillo. 1999. In vitro microbial fermentation of tropical grasses at an advanced maturity stage. Anim. Feed Sci. and Technol. 83:145-157.

Ørskov, E. R. and I. McDonald. 1979. The estimation of protein degradability in the rumen from incubation measurements weighted according to rate of passage. J. Agric. Sci. (Camb.). 92:499-503.
Poppi, D. M., D. J. Minson and J. H. Ternouth. 1981. Studies of cattle and sheep eating leaf and stem fractions of grasses. 1. The voluntary intake, digestibility and retention time in the reticulo-rumen. Aust. J. Agric. Res. 32:99-108.

SAS. 1990. Statistical analysis system. SAS/STAT User's guide. Statistical analysis Institute, Inc. Carry, NC. USA.

Serra, A. B., S. D. Serra, E. A. Orden, L. C. Cruz, K. Nakamura and T. Fujihara. 1997. Variability in ash, crude protein, detergent fiber and mineral content of some minor plant species collected from pastures grazed by goats. Asian-Aust. J. Anim. Sci. 10:28-34.

Sullivan, J. T. 1973. Drying and storing herbage as hay. In: Chemistry and Biochemistry of Herbage. (Ed. G. W. Butler and R. W. Bailey). pp. 1-31. Academic Press, London and New York.

Tequia, E. R. Ørskov and D. J. Kyle. 1999. A note on ruminal in situ degradability and in vitro gas production of some West African grass species and multipurpose legume tree leaves. J. Anim. Feed Sci. 8:415-424.

Tilley, J. M. A. and R. A. Terry. 1963. A two-stage technique for the in vitro digestion of forage crops. J. Br. Grassland Soci. 18:104-111.

Tudsri, S. and C. Kaewkunya. 2002. Effect of Leucaena row spacing and cutting intensity on the growth of Leucaena and three associated grasses in Thailand. Asian-Aust. J. Anim. Sci. 15:986-991. 